\title{
Media system in China: a Chinese perspective
}

\author{
Austin Jun Luo
}

Received: 4 November 2014/Revised: 31 January 2015/Accepted: 13 February 2015/

Published online: 13 March 2015

(C) Academy for International Communication of Chinese Culture 2015

\begin{abstract}
The media system in China is not totally different from the systems in all other countries in the world. This paper will explain the nature of the media system in China and its internal mechanics from a Chinese perspective. The media system in China is a combination of different media philosophies and the result of the long history of Chinese civilisation. In this system, the Chinese Communist Party, government, private enterprises, media professionals, public individuals and Chinese culture play different roles and provide different forces from different directions and in different fashions. By analysing each force and their interaction inside the media system in China, this paper elucidates the mechanics of the media system in China and attempts to explore the possibility of using these mechanics as a new model to explain media phenomena in China.
\end{abstract}

Keywords Media system · In China - Chinese perspectvie · Driving forces · Mechannics · Model

\section{Background}

Everyone knows that the CCTV Spring Festival Gala has long dominated Chinese New Year's Eve. Figures from the CSM Media Research Company, a leading company in audience rating research of the Chinese TV market, indicate that the audience rating for the 2013 CCTV Spring Festival Gala on CCTV-1 was 11.362 per cent (Qianwen 2013). Before the title sequence starts, the commercial break is considered the highest value spot in the TV market. This extreme commercial value of the break produces an illusion that the Chinese media is fully commercialised or marketised, but this is not the case. When producing The Gala 2014, CCTV

\footnotetext{
A. J. Luo $(\bowtie)$

Academy for International Communication of Chinese Culture, Beijing Normal University, Haidian,

Beijing, China

e-mail: luojun@bnu.edu.cn
} 
announced that one of the biggest blockbuster film directors, Feng Xiaogang, ${ }^{1}$ would be responsible for the content (Schwankert 2013). Shortly after this, Feng Xiaogang told the press that his response to all the congratulations is that he does not thank the authorities. Instead, the authorities should thank him. The reason Feng said this is most likely that he realised that the position of creating content for the largest national ceremony in China is not an easy job, as it needs to satisfy all aspects of Chinese society, the Communist Party of China, the Chinese government, the public, the press, the audience, the sponsors, etc., and the person responsible takes on the greatest risk in balancing these multiple needs.

The Spring Festival Gala can provide a larger amount of additional meaning than any other ordinary entertainment show in China. The CPC needs this program to be controlled in such a way to show the 'mainstream value of socialism,' and censorship is crucial to guaranteeing the content. The government needs this TV program to function as a national rite to demonstrate the prosperity of this country. CCTV needs this program to carry commercials and generate revenue. TV professionals inside CCTV need this program to reassure their professional standards. Almost all the celebrities in the performing arts or show business need this stage so as to obtain the highest levels of exposure and improve their image. Large companies, such as beverage, telecommunication, bank and Internet companies, purchase naming rights, commercial breaks or even product placement during this program because this show has the highest viewing share in China. The public has been spoiled by this free entertainment, and even today, some of them cannot imagine a Chinese New Year's Eve without this program.

With the increasingly wider application of Internet and mobile communication, the public has become increasingly integrated with the creation of Spring Festival Gala social media content. Because Chinese New Year's Eve is a time where the family gathers, the typical situation involves a 3-generation family, as large as possible, gathered in front of their TV set while making dumplings for the first New Year's meal in northern China or having the New Year's Eve Dinner in southern China. The Gala adds a mood of celebration in the house as people laugh, discuss and enjoy the performance. In 2013, the statistics (Millward 2013) of Sina Weibo, a microblog service similar to Twitter in China, indicate that, during the seven hours of the show, Sina Weibo users, including the audience, the performers and directors, live tweeted 19,582,947 times.

Contemporary Chinese culture also has a condensed presentation during the Spring Festival Gala. This is the demand of everyone in China, which can be understood as cultural motivation to maintain self-confidence and pride. On the other hand, the Spring Festival Gala is deeply influenced by Chinese culture, and it has become a cultural icon and a new Chinese cultural component.

The story of the Spring Festival Gala showcases the intricacy of the media system in China. According to a report (崔保国 2013) released by Tsinghua University, there are currently three categories of media in China: Traditional Media, Internet Media and Mobile Media. Newspaper, periodical journals, books, radio, television and movies are

\footnotetext{
${ }^{1}$ Feng Xiaogang, born 1958 in Beijing, China, is a Chinese film director. He is well known in China as being a highly successful commercial filmmaker whose comedic films do consistently well in the box office.
} 
in the category of traditional media, whereas portal websites, video sites, search engines, social media, online games and electronic commerce belong to Internet media. Every type of media related to handsets could be defined as Mobile Media. In traditional media, the ownership is mainly the CPC or the government. Usually, telecommunication carriers or mobile service providers, either by their own or along with investment companies, control and establish Internet media and Mobile Media aspects.

The media system is a set of interacting and interdependent organisations or groups of people, combined with the above-mentioned three categories of media, forming an integrated whole. It is a highlighted social system focusing on the components directly reacting with media. The media system in China is a dynamically balanced system between the following driving forces. This paper will discuss what the forces are and how they interact with media and with each other, and by doing this, provide a new approach to understanding the media system in China.

\section{Driving forces of the media system in China}

As visualised in Fig. 1, the media system in China is a relatively closed system. There are at least six existing forces influencing Chinese media synchronously

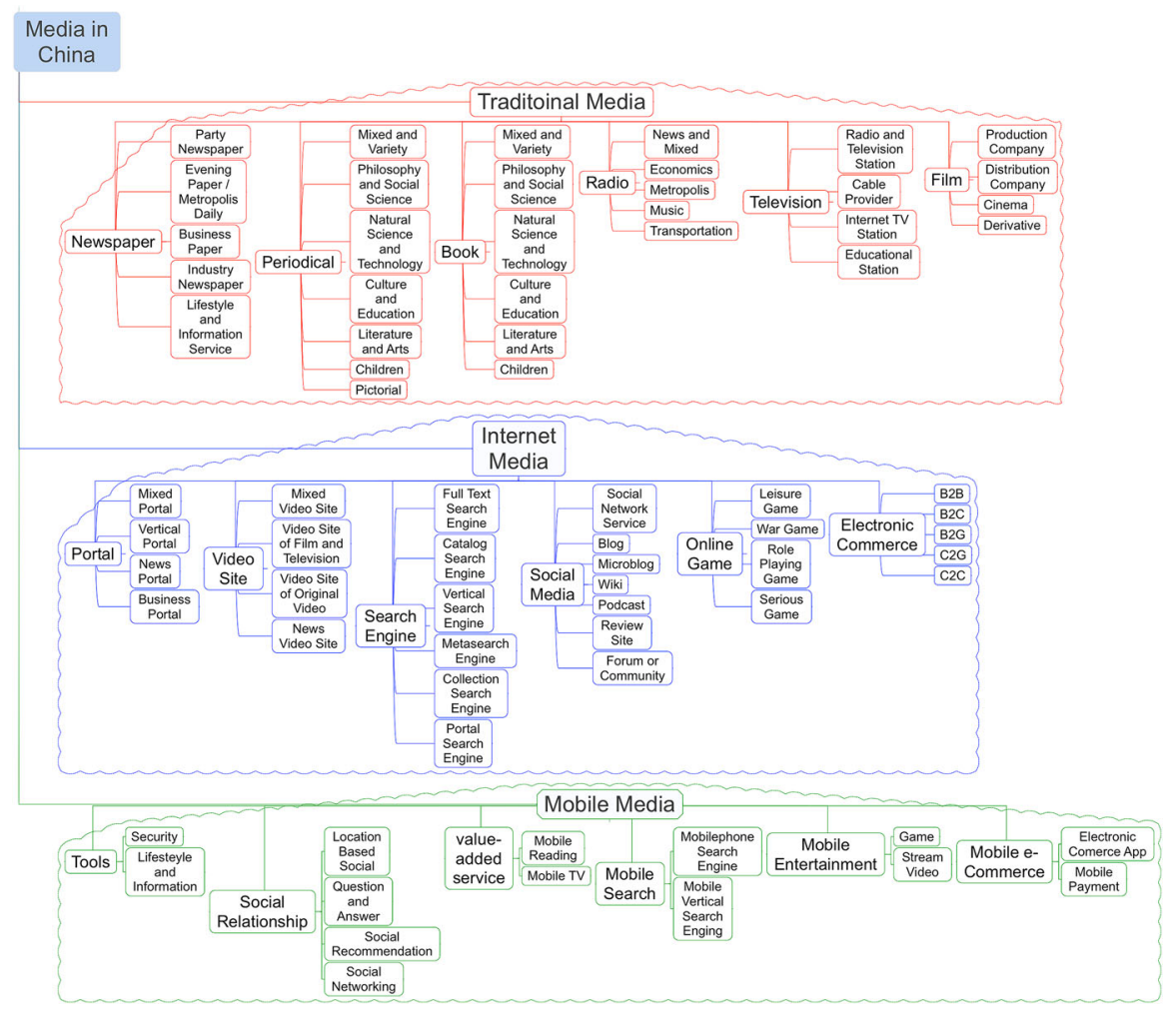

Fig. 1 Media in China (remade by author with data from Tsinghua University) 
through different organisational or social channels, which could be designated the Party Force, Governmental Force, Capital Force, Professional Force, Individual Force and Cultural Force.

Party Force could be defined as the control and influence from the CPC, which is overall directed through the Central Propaganda Department.

Governmental Force is the power generated from the central government and embedded in organisations in and regulations from the State Administration of Press, Publication, Radio, Film and Television, coming all the way through the mechanism of multiple layers of administrational bureaus under the central government, from the provincial, municipal or prefectural levels to the county level.

When scholars examine the Party Force and Governmental Force together and observe their combined contribution to the media system in China, they tend to label it as the Party-State model or authoritarianism model.

Capital Force is the impetus from the 'free market', which started to be one of the players in Chinese media after the opening up policy in the late 1970s and early 1980s. When the media found a strong motivation to make a profit, in the form of media buyers, capital owners invested money into media and exerted media content. Many scholars noticed that this force has a strong effect on the media system in China. The above three forces are mostly discussed by scholars (Zhao 1998, 2004; Sparks 2008; Murphy 2007; Stockmann 2012), and regarded as the main forces influencing media, and scholars label the media system that only involves these three forces as "Commercialised Authoritarianism" or "Marketised Authoritarianism". The problem, however, is that there are three additional forces being ignored.

The media professionals working for media entities internally generate Professional Force, which is the only inside-out power affecting media. The media professionals do not occupy the decision-making positions, but they are media operators, such as editors-in-chief, producers, directors, etc. They are usually educated as journalists with almost all curricula similar to that of Western media education, and their collective tendency is to treat media as a public service.

Individual Force describes the influence over media from individual citizens. Citizens, sometimes in forms of public or group, either as readers or as audiences, receive influence from media and return their own pressure on media. The public could previously only interact with the media in a limited manner. With the popularisation of the Internet and mobile Internet, individual citizens can access media facilities with increasing ease, generating their own content or interacting with traditional media.

Culture is an intangible driver of media in China. Over thousands of years of history, the Chinese have created a strong culture and, at the same time, have formed their own moral code along the development and progress of Chinese society. In China, culture may play a more obvious role than in other countries. Cultural Force is the sixth force driving media. For example, the Spring Festival Gala on CCTV1 is the most important and iconic TV program in China and is widely considered as a new cultural element. Culture of course is notoriously difficult to measure. Since this paper is establishing a qualitative framework and is not intended to be quantitative, this paper may trigger further studies on how culture is integrated in any meaningful way into the model. 
It is people who generate all forces influencing media in China. Excluding Cultural Force, each force is produced by a specific group of people, whereas Cultural Force is produced by all people in Chinese culture and not from any specific group of people. The people join the CPC and become Party members who produce the Party Force. Government does not function without officials working in it. Governmental officials and civil servants create Governmental Force. People who pay media want significant influence on how to obtain their advertisement or sponsorship published in media, so media buyers are the group of people providing Capital Force. This is the method through which people create Capital Force. Professional Force is only possible when the group of people working inside the media want to clearly express their independent ideas or be heard significantly. Individual Force comes from individual people, in the form of isolated people or groups of people. On the contrary, it is common sense that the Cultural Force does not come from any specific group of people, because cultural impact always comes from all the people living in China in the form of collective awareness or unconsciousness.

\section{Influence of different forces}

Different forces influence media in different ways and follow different philosophies.

\section{How Party Force influences media in China}

If the CPC were the only party in China, or if the CPC were a perfect branch of the Soviet Communist Party, then the CPC's media philosophy should be naturally Soviet Communist, which was first defined and discussed by Siebert (1956). However, the truth is that the CPC has had Chinese characteristics since its birth, but we have to agree that its philosophy still falls into the general zone of Communism. Zhao pointed out that (Zhao 1998) Party journalism has a long history, which can be tracked back to "radical journals of the late 1910s and early 1920s in which students and intellectuals voiced their opposition to imperialism and to Chinese warlords." From the founding of the CPC in 1921 to the establishment of the People's Republic of China, the Party press played a key role as an organ. There were 34 newspapers and journals in the Jiangxi Soviet. In the era of Yan'an, Mao Zedong released a famous speech May 1942 entitled 'Talks at The Yan'an Forum on Literature and Art", which has continued and still has impacted the Chinese Party press. In his talk, Mao said the following:

The problem of class stand: Our stand is that of the proletariat and of the masses. For members of the Communist Party, this means keeping to the stand of the Party, keeping to Party spirit and Party policy.

This talk by Mao defined the basic purpose of the Party press in China and disciplined its tone and manner. After the CPC established the People's Republic of 
China in 1949 and even after the external openness facilitated by Deng Xiaoping since the 1980s, this concept has not changed.

To achieve the Party organ's goal, the CPC has been influencing media through ownership, sponsorship and censorship. In the category of traditional media, the CPC has maintained ownership of one of the largest newspapers in China, People's Daily, since its launch in 1949. In addition, the CPC central committee also owns a bi-monthly Party journal, Qiu Shi (Seeking Truth), which was launched in June 1988 under directions from Deng Xiaoping, replacing the Red Flag periodical. From the CPC central committee organisational chart, we can find the rank of People's Daily is the highest of all newspapers in the market. At the provincial and prefectural levels, all Party committees produce their own dailies (Murphy 2007).

The CPC does not own every media source in China, but its propaganda department is in charge of censorship of all media content. Censorship is the active attempt by the Party to suppress material that a production entity plans to compose or has already composed. All the above-mentioned media function not mainly as vehicles of social communication or as the voice of different groups but as "mouthpieces" of the Party or as "Propaganda tools" to promote the official ideology and consolidate the power of the state. Thus, censorship is vital in this system. On the other hand, the media itself will conduct self-censorship as a response.

At the nationwide macroscale, the Central Propaganda Department, through its well-organised system, oversees the Propaganda and Education System (xuanjiao xitong) that monitors, instructs and censors all of China's newspapers and magazines, film, television and radio broadcasting, the Internet, the publishing industry and all aspects of cultural and information production from the highest to the lowest levels of society.

At the level of corporate administration, there is a key person, the Party branch secretary, who is responsible for implementing the Party's tasks. This could be interpreted as the human resource promise of Party Force in the media system.

\section{How Governmental Force influences the media in China}

In discussing the state role of the Russian media system, Smaele (Dobek-Ostrowska 2010) listed four roles: owner, funder, regulator and censor. The situation is exactly the same in China. The Chinese central government regulates the media in the philosophy of authoritarianism, which emphasizes the national benefit as first priority. It is natural that government tends to amplify national interest. The authoritarian concept can be traced back to Plato, in his works The Public, Statesman and the Laws, and The Prince by Niccolo Machiavelli.

If we agree that authoritarian philosophy is commonly represented in the governance of society in three main areas, i.e. decree, legislative process and religious doctrine, then we find this philosophy has been widely practiced by Chinese dynasties throughout Chinese history, but in another totally independent discourse system. Chinese political philosophy dates back to the Spring and Autumn Period, specifically Confucius in the 6th century BC. Chinese political philosophy developed as a response to the social and political breakdown of the country, which 
were characteristics of the Spring and Autumn Period and the Warring States period. The major philosophies during the period, i.e. Confucianism, Legalism, Mohism, Agrarianism and Taoism, each had a political aspect to their philosophical schools. Philosophers, such as Confucius, Mencius and Mozi, focused on political unity and political stability as the basis of their political philosophies. Confucianism advocated a hierarchical, meritocratic government based on empathy, loyalty and interpersonal relationships. Legalism advocated a highly authoritarian government based on draconian punishments and laws. Mohism advocated a communal, decentralised government centred on frugality and ascetism. The Agrarians advocated a peasant utopian communalism and egalitarianism. Taoism advocated a proto-anarchism. Legalism was the dominant political philosophy of the Qin Dynasty but was replaced by State Confucianism in the Han Dynasty. Prior to China's adoption of communism in 1949, State Confucianism remained the dominant political philosophy of China up to the twentieth century, and its influence has remained marked until now.

Ancient Chinese political philosophy had faith in the way of heaven, the will of heaven, the fortune of heaven and the principles of heaven. As the son of heaven, the emperor was determined by heaven, and this was the reason for his incontestable authority. The ancient Chinese political system was inclusive (史仲文,陈桥生 2010), which exhibited some characteristics of authoritarianism. For example, imperial authority, the sovereign power, surmounted all laws, and the ethical codes replaced laws in tradition. These traditions have been embedded and resurrected in the current government behaviours.

Government Force interrupts media before any content has been produced. No matter the form or format of the content, media producers need to apply for a certificate or license in advance. The State Administration of Press, Publication, Radio, Film and Television issues licenses for most traditional media, whereas the Ministry of Industry and Information Technology takes care of the online and mobile media.

Governmental Force controls content through censorship by governmental departments and self-censorship by media. Punishment is another procedure controlling content, including the closing of a facility, the separation of a cadre from his post, the dismissal of media professionals or even arrest if there is criminal evidence involved.

The regulations released from government results in significant modification of media behaviours. In 2011, The State Administration of Radio, Film and Television issued new rules restricting commercials from interrupting TV dramas, allowing them to air only back-to-back between programs. It has been reported the restrictions, which went into effect at the beginning of 2012, were intended to spur broadcasters to show more cultural programming, helping them to uphold a "public service"(Burkitt 2011).

How Capital Force influences the media in China

The first question about Capital Force is who is holding the capital and buying media in China? In the broad term, media buyers include advertising agencies and direct sponsors, who sign contracts with media entities to publish advertisements, 
build partnership with media or purchase product placement opportunities. The media buyers form the group of people who produce the Capital Force, and they represent either private capital or state-owned capital, regardless of whether they are from professional investment companies or from ordinary enterprises.

Capital Force in China displays a tendency to believe in the fantasy of the free market, and the people involved in Capital Force pretend to act as if they are in the USA where libertarian philosophy is fully developed and practiced. In the governance of society, libertarian media philosophy is often demonstrated in two aspects: constitutional law, which honours the private ownership of property, and legislative and judicial law, which allows a free market in which media content and producers can compete against one another. Indeed, President $\mathrm{Hu}$ Jintao has published the Property Law of the People's Republic of China (Hu 2011). Historically, the Capital Force's first change to media in China has been with regard to ownership, starting from the opening policy established in the 1980s. Taking the example of newspapers, according to Daniela Stockmann's investigation (Stockmann 2012), Chinese media practitioners distinguish between three types of newspapers, official, semi-official and commercialised papers. Among these three types, the commercialised papers can be owned by private capital or joint capital between the private sector and organisations of either the government or Party. For example, the biggest search engine, Baidu, is a public company and has been listed on the Nasdaq Stock Exchange since 2005.

Capital Force follows Liberalism as a media philosophy, which is related to the truth about capital in the Chinese media market, as mentioned by many scholars, that all types of media have joined the market competition and chase after profit. However, in comparison to fully commercialised and free media markets, such as in the US, there is another difference in Capital Force influence over media, which is the market response to media performance. In a free market, media companies gain profit because of good performance and lose profit or even go bankrupt when their performance is bad. Using the term invented by Adam Smith, the media market is balanced by an "invisible hand", which encourages better performance and punishes worse competition. In China, in addition to the "invisible hand", there is a "visible hand" operated by either the CPC or government, or sometimes both, which sometimes interrupts and confuses the market response.

At the corporation level of media management, the key role involved in practicing Capital Force is the sales manager in charge of gaining income. Regardless of the ownership or category the media organisation belongs to, this role is crucial to acquiring revenue, making marketing plans, supervising branding and negotiating with media buyers, among other such related factors.

With the growth of advertisement, the media's capacity to carry advertisement has reached its limits and sometimes is already overused. In addition, after many years of being targeted by brand or product advertisements, audiences have become increasingly discriminating. As a result, paid content, such as product placement and infomercials, ${ }^{2}$ have recently been broadly used in the Chinese media. This will

\footnotetext{
${ }^{2}$ A kind of commercial in the form of information.
} 
change the landscape of the Capital Force affecting media in China so that it is much more ambiguous.

\section{How Professional Force influences the media in China}

To explain the journalistic variations that cannot be clearly revealed using a statepolicy press model alone, Ostini and Ostini (2002) examined the importance of professionalism in a new media model other than the normative model discussed in Four Theories of the Press (Siebert 1956). When discussing the post-Soviet media model, Oates (2007) highlighted the evidence of the lack of journalistic professionalism, which exists, but is not complete and not useful in the protection of media as the Fourth Estate. The situation of the professionalism in media in China is similar and different.

Wu Fei and Wu Feng (吴飞 and 吴风 2004) conducted a survey on the construction of ideas of journalistic professionalism among Chinese media professionals. One of the interesting results from their research work is that newspaper professionals rank "Factual Accuracy" as the most important achievement, whereas television professionals state "Objective Reporting" as the first priority. The professionals also pursue other career goals, such as "Timeliness", "Exclusive Reporting”, "Deep Investigation", "Attractiveness", "Justice", "Balanced Reporting", "Originality" and "Comprehensiveness". The professionals working in newspaper and television react slightly differently to these indexes, but they both gave "Balanced Reporting" the lowest importance. This lack of concern over balance is most likely because there are too many forces for the professionals to balance, and the balance is always difficult. Arguably, the lack of concern with balance is because they know it is not expected of them in this system. At the minimum, Wu's research proved the existence of professionalism in the Chinese media.

The contemporary Chinese press was inaugurated at the end of the nineteenth century, including the Shen Bao, Xin Wen Bao and $\mathrm{Zi} \mathrm{Lin} \mathrm{Xi} \mathrm{Hu} \mathrm{Bao,} \mathrm{during} \mathrm{the}$ awakening of national consciousness as a result of coming into contact with previously unknown European powers (Passin 1963). September 1, 1926, three journalists, Wu Dingchang, Hu Zhengzhi and Zhang Jiluan, re-established a newspaper, the Ta Kung Pao, and announced "4-No-ism" as its slogan-"no party affiliation, no political endorsement, no self-promotion, no ignorance ( $b u$ dang, $b u$ mai, bu si, bu mang 不党、不卖、不私、不盲)” (侯迎忠 2005) and pledged to say no to all political parties, governments, commercial companies and individual persons seeking to influence them. Such protection of editorial rights generated a defending force against other forces in the media system, sometimes causing tragedies. A possible new version of this type of conflict is a CCTV producer's resignation because of his blogs (Chin 2013).

The vehicle for Professional Force to affect media is the pressure exerted back on the forces from the CPC, the government and the capital. As shown in Fig. 2, we can find that the direction of Party Force, Governmental Force and Capital Force are from outside the media, whereas the Professional Force provides a counterforce against these three forces. 


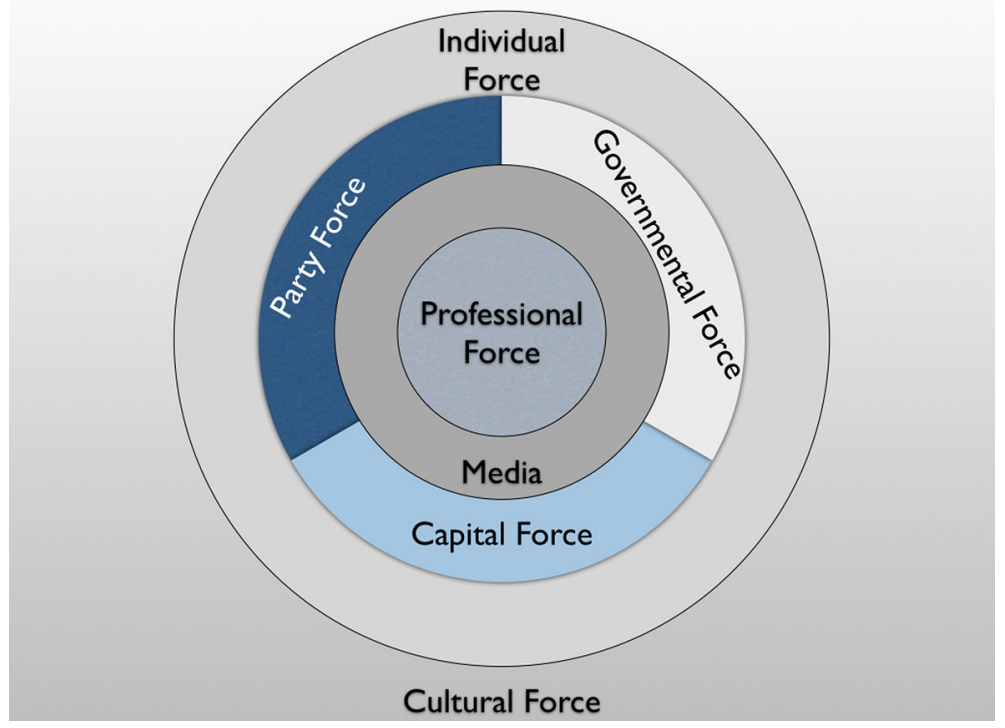

Fig. 2 Media in China and its affecting factors

Media professionalism is not a new concept in China. Media practitioners cannot be equated with the scholar-officials (儒生) of ancient dynasties, but both contemporary media professionals and ancient scholar-officials share the same heritage of “Emotion to Family and Country” (Jia Guo Qing Huai, 家国情怀). The scholar-official tradition in ancient dynasties gives Chinese intellectuals the heritage and right to express themselves independently on behalf of protecting universal values (Fairbank and Goldman 2006). The scholar-officials were selected by an imperial examination system, which was an institutionalised form of the Confucian aphorism, "If one wants to be an official, he has to study well." After being transferred to an official, the scholar became part of the administrative machine and took the role of "Shepherd" to look after the public - the "Sheep" (Boxu 2010). The heritage of being a "Shepherd" and helping emperors to control the content of the media is still considered part of professionalism among the Chinese media practitioners, especially in the mainstream media. It is inconceivable that the national Governmental Force, either an emperor or a central government, can control the media without insiders' support (Table 1).

How Individual Force influences the media in China

Individual here is a term referring to members of the public identified as consumers, such as audience members, readers, listeners or users in media systems. The media executives or members, when consuming media content, are also considered as individuals. 


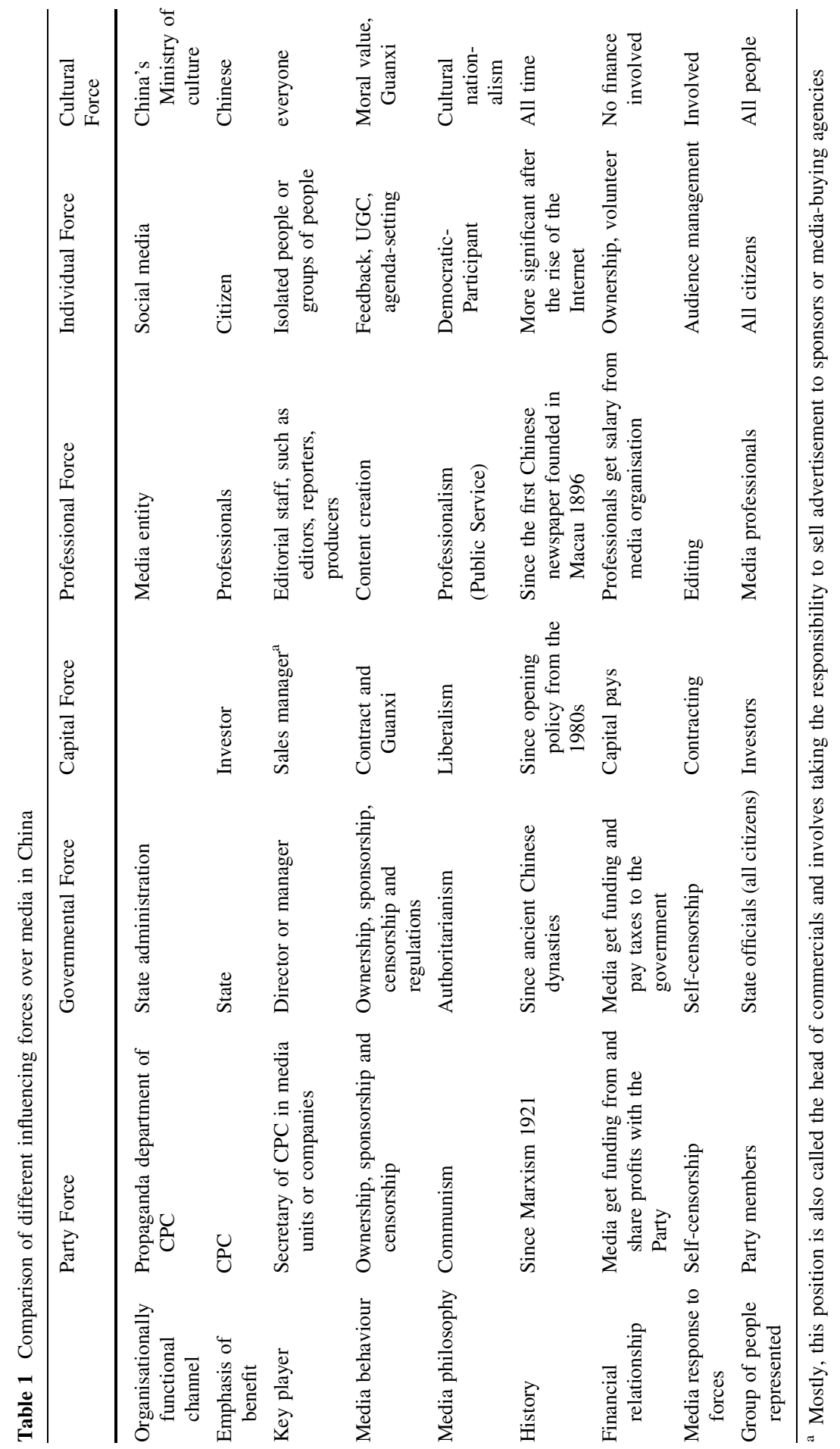


Via the media audience, Individual Force acts on media content, usually, without direct financial involvement. In the traditional situation, for example, when CCTV is producing a program, the Individual Force is only exerted via audience feedback, which is a weak link between the producer and audience, because this volunteering response is naturally motivated. CCTV welcomes suggestions for change that fit their basic assumptions about their audience and that do not challenge the pressure from the CPC and government, even if the suggestions mean giving up some of the routines they are used to. However, if the audience's demands to a media organisation will cause tremendous readjustment from its basic policies or values, the production personnel will respond negatively or even ignore this message from the individual audience.

Individual Force can own media, thanks to the Internet, and further change is being recognised as the mobile Internet has become more easily accessible. The audience was a disenfranchised group that had been excluded from media production processes dominated by the Party, governments and corporations before. However, the relationship between media and individuals changed after the wide use of the Internet. In a series of writings, Jay Rosen with other coauthors (Merritt and Rosen 1995; Rosen and Merritt 1994; Rosen 1996) invented a media philosophy (Democratic-Participant) that provides a theory for individuals participating in the media system. The following two active methods by which individuals engage in social media practice need to be emphasised. Firstly, Individual Force provides feedback via the audience, as discussed above. The increasing feasibility for individuals to interact with the media through the Internet and mobile Internet results in a trigger of the amount of response back to media or about the media content. The response speed audience feedback is faster than ever. In addition, the amount of feedback is enormous, and the frequency with which the audiences send back information is higher. With the Internet and mobile Internet, the pressure exerted on individuals on the media is scaled up. Secondly, Individual Force creates content. UGC, User-Generated Content, has become part of the media itself, which means individuals are contributing directly to creating content and not only to consuming content passively as they previously did.

From the perspective of ownership, Individual Force is also now capable of generating media content through many business platforms, such as Apple's iTunes store and Google's Google Play.

Individual Force pushes the media as well as Party Force, Governmental Force and Capital Force simultaneously. The case of Lei Zhengfu demonstrates this feature. Lei was sacked from his position a few days after a sex video recorded 5 years ago went viral online via the popular microblog service Sina Weibo. The video was created for the purpose of blackmail by the collusion of a property developer and an 18-year-old girl. On November 20, 2011, at 4 pm, a series of hotel room sex screenshots titled "Lei, the secretary who accepts sex bribes" were published on a personal website called "Civil Supervision". Lei Zhengfu was the Beibei District of Chongqing Party Secretary at the time. A few hours later, these screenshots started to go viral through microblogs. Sixty-three hours after the screenshots first went online, on November 23, a Chongqing Municipal People's 
Government information office official made an announcement that the government had proved the male shown in the video was Lei and stated he would be removed from his position. This case is believed to be a result of "Network supervision by public opinion"(吴永强 2012).

Individual Force leads a significant social change and agenda-setting procedure in the public sphere, which was led formerly by traditional media and aimed to interpret mainly the will of the CPC or government. In the above case, social media operated by an individual triggered the whole communication chain, which lead to all levels of the media being involved.

\section{How Cultural Force influences the media in China}

Chinese culture is the combination of social relationships, customs, values, norms and institutions that constitute and inform society.

Chinese culture provides an intangible foundation for the media system, especially in that China has a long history. Many Chinese people will round up their history of civilisation to greater than approximately 5000 years, because there have been versions of a Chinese state for around 5000 years. Martin Jacques, in his best-seller book When China Rules The World: The End of the Western World and the Birth of a New Global Order, indicates that "China is not just a nation-state" "but a civilisation-state." Chinese identity is "overwhelmingly a product of its civilizational history" (Martin 2009). The long history of and heavy dependence on civilisation give rise to the reality that Chinese culture has a strong impact over the media and media system in China. On the other hand, if there is a philosophy behind Cultural Force in the media system in China, Cultural Nationalism would be the correct one. This paradox reflects the spatial and temporal dimensions culture force that takes place in the media system. From the perspective of time, Chinese culture has input cultural elements nourished by civilisation history. In regards to spatial span, Chinese culture does not refuse a national boundary and stands out in the form of nationalism. Townsend (1992) discussed the evolution from culturalism to nationalism in China, alerted the differentiation between culturalism and nationalism. It is worth repeating that Chinese Culturalism is both a Chinese identity and the movement maintaining such an identity, whereas Chinese Cultural Nationalism vigorously defends Chinese culture against foreign competitors. In the political domain, nationalism is also a concept of political identity.

Compared with the existed media Developmental Philosophy (McKenzie 2006) holding that media are to improve the social conditions of developing nations by international assistance, Cultural Nationalism pays more attention to the cultural meaning of media content and its impact on culture in return, within Chinese borders.

To enhance the understanding about how culture influences media, we may need to examine Chinese culture more deeply and explore how its uniqueness influences the Chinese media system. The theoretical frames measuring culture worldwide, such as Culture Dimensions (Hofstede and Bond 1988), World Value Survey and 
IBM's Comparative Attitude Surveys (Hofstede and Bond 1988), have provided approaches from a Western perspective and highlighted some interesting points. For example, respect for age and hierarchy is a hallmark of Chinese culture (Faure and Fang 2008). Fang (2012) introduced a Yin-Yang model to explain culture, which is most likely the theory that is most accurate for Chinese culture in particular.

There is no room for the discussion of Chinese culture is in this paper, but we can at least point out that Yin and Yang could be a key concept to decode the cultural influence in the media system. Chinese ancients believe that all things are composed of yin and yang moving eternally and converting into each other, which is the basic law of the whole universe. The simple dialectical thought of coexistence of yin and yang is one of the basics of traditional Chinese philosophical thought.

Chinese culture produces a context in which the media system takes effect. In addition, Chinese cultural characteristics affect the texture of the media system as a whole. Indeed, in every media system at the national level, culture plays the same role. Robert McKenzie illustrated elements of media system as a tree in his book, Comparing Media from around the World, and the cultural characteristics were compared with soil "representing local or domestic condition that influence more subtle attributes of the tree."(McKenzie 2006) In Fig. 2, Culture Force is not interdicted by Individual Force or any other forces. Instead, it is a systematic force existing everywhere and affects the media with all other forces synchronously. It is natural that Cultural Force does not produce media ownership, which displays similarity to Professional Force (Figs. 3, 4).

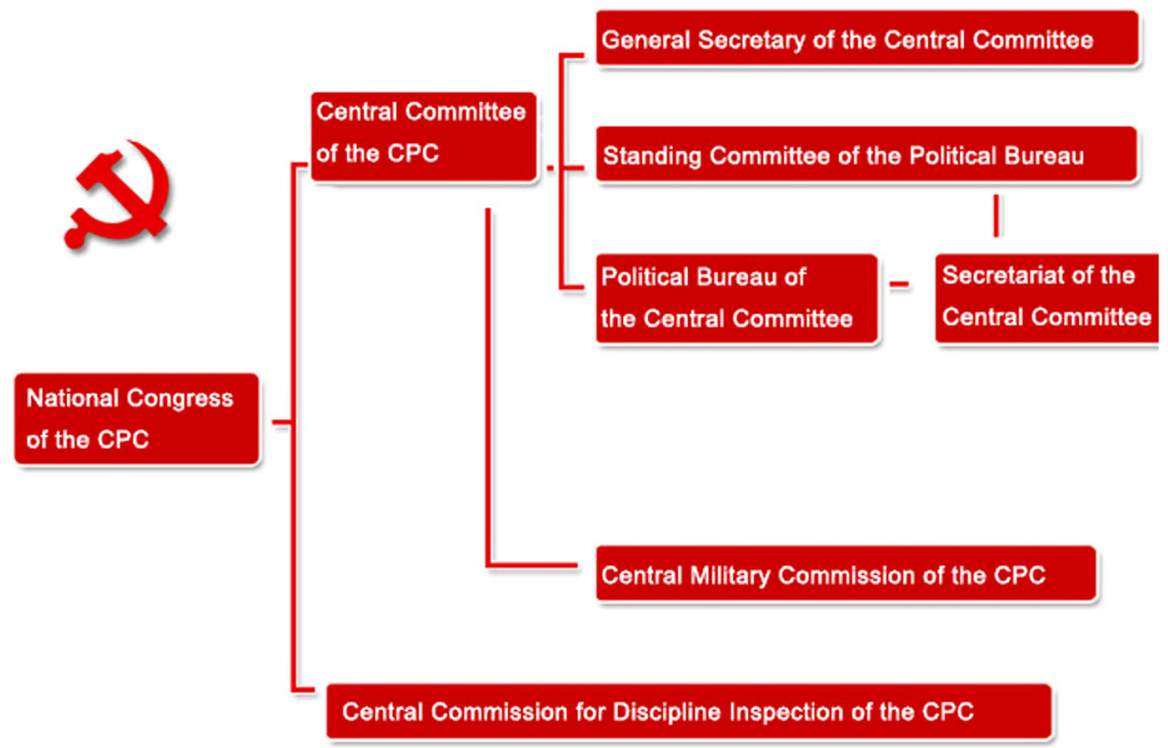

Fig. 3 The central organisations of the CPC. Exported from http://www.china-embassy.org/eng/zt/ 18th_CPC_National_Congress_Eng/t989630.htm 
Fig. 4 Yin and Yang

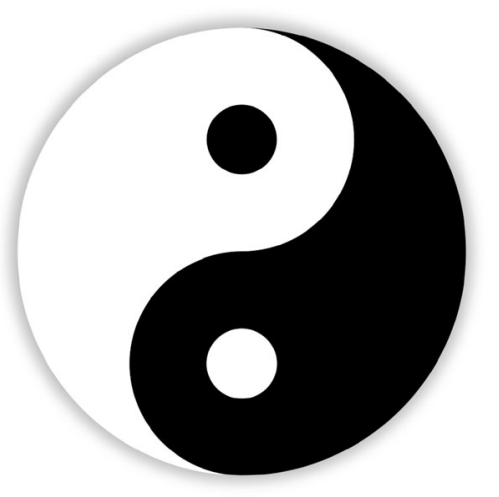

\section{Different forces in Laozi's social system}

These forces exert separate influence over media and media system simultaneously, but they are not isolated. Instead, they are interactive and integrated.

To better understand the systematic feature of the media system in China, a systematic thinking frame provided in the ancient Tao Te Ching by Laozi needs to be mentioned. Chinese ancient philosophy believes the universe has three layers, Heaven (Tian 天), Human (or, Society) (Ren 人) and Earth (Di 地). In chapter 54 of Tao Te Ching, Laozi divided the Chinese social system into five levels: Individual Level (Shen 身), Family Level (Jia 家), Community Level (Xiang 乡), National Level (Guo 国) and World Level (Tian Xia 天下).

Hence,

According to your self

Consider yourself,

According to your family

Consider your family,

According to your community

Consider the community,

According to your nation

Consider the nation,

According to all world

Consider the world.

Chapter 54, Tao Te Ching

This ladder-like system builds a vertical social scale starting from the Individual Level_- "Yourself" and then enlarges to the Family Level, which contains more individuals and becomes the most basic cell of social organisation-family. Larger than family, there is the Community Level, which originally meant local governmental authority and also has multiple meanings including "neighbourhood" or "a group of people". Then, the scale zooms up to National Level, followed by World Level. Behind this thinking style, all levels of society are defined by and related to humans, in which there can be found clues concerning the nature of 


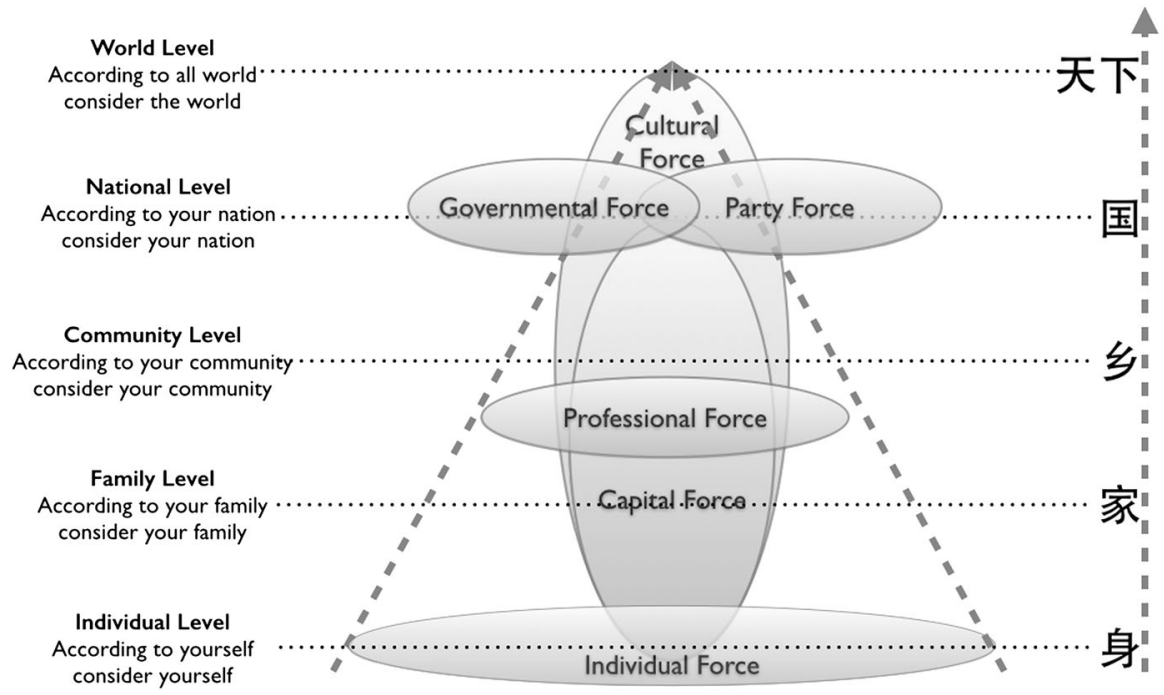

Fig. 5 Different forces in Laozi's social system

humanity. When we abstract the above-mentioned six forces into such a social system, without considering their reaction to media in between, as in Fig. 5, we can see different forces are distributed on different social levels and cover different ranges.

Using Laozi's methodology, we can find Individual Force at the bottom of Laozi's social structure. Cultural Force has effects throughout the whole system. Governmental Force and Party Force rule the National Level (Guo 国). Capital Force represents people or corporations holding money, and its effect is only available under regulation of Governmental Force and Party Force and affect all levels below the National Level. Because Professional Force can just serve for a special group of people-inside the media, with a size between family and group, it could be placed between the Family Level and Community Level.

In this system, each force competes against each other to convey its influence to media. Announced in 2011 and imposed in 2012, aiming at stopping the overemphasis on purely entertainment programs in the satellite television channels in China, State Administration of Press, Publication, Radio, Film and Television released an order, Opinions on Strengthening The Program Management of Satellite Television Channels. SAPPRFT required that there should not be more than nine programs of the above genres from 19:30 to 22:00 every day for all satellite TV channels as a whole, and each channel should not broadcast more than two programs of the above genres every week and not more than $90 \mathrm{~min}$ every day. SAPPRFT also demanded the satellite TV channels increase the proportion of documentary programs, news programs, educational programs, programs for children and youth and programs about economic issues and science. The policy had a great impact on those TV channels that had been focusing on producing entertainment programs, among which included Hunan Television, Dragon 
Television, Jiangsu Television, Zhejiang Television and Shenzhen Satellite TV. Some of the programs that had been planned need to be suspended. Companies focusing on license purchasing for international formats have greatly suffered from this policy, which reflects the impact from Governmental Force to Capital Force.

On occasion, because each force represents a different group or class of people, the contradiction between forces is nothing but reflections of social problems. This is another level of media force competition.

The forces are not enemies. On many occasions, each force has a tendency to cooperate with some forces or even all other forces to achieve its goal. This competitive-collaboration relationship is a self-balancing mechanism inside the media system in China. As the media system seeks its own balance and harmony, the boundaries between the forces are also becoming increasingly unclear, and the source of forces co-affecting the media are harder to recognise. Taking the Spring Festival Gala 2014 as an example again, far before the gala, CCTV3, the variety channel of CCTV, opened a star-recruiting program, Road to Spring Festival Gala, specifically to find performers for the Gala. Like other audience voting programs, such as American Idol, this program takes advantage of Individual Force and resolves public opinion into media content.

\section{Conclusion}

In the Chinese media system, there are six forces that all affect the media, which are defined in this paper as Party Force, Governmental Force, Capital Force, Professional Force, Individual Force and Cultural Force.

From the perspective of ownership, Party Force, Governmental Force, Capital Force and Individual Force can physically control media, whereas Professional and Cultural Forces can only impact media in intangible ways. In regards to regulation, Governmental Force dominates regulation, although other forces influence it when government officials make any decisions.

The overall media philosophy behind the media system in China is a combination of Communism, Authoritarianism, Liberalism, Professionalism, Democratic-Participant and Chinese Culturalism.

Each force competes against each other in the social system and also cooperates with each other.

\section{Discussion}

It is ironic that, by now, there is no such media strictly based on the philosophy of "Social Responsibility" or "Public Service" in China, on a model similar to the BBC, NHK or PBS. This type of media concept (Siebert 1956) believes that media organisations are not completely free to publish what they like as they have certain obligations to society to provide information and balance. The media should provide access to all groups. The media and the government are partners in constructing civil society. In 1947, a group of scholars issued a report, A Free and Responsible 
Press, after studying the role of media in modern-day society and incubated social responsibility as a philosophy for a media system, which currently is practiced in a wide variety of countries such as the United Kingdom. Among the list of consultants, there was a Chinese scholar, Hu Shih, who was once the President of Beijing University and the Chinese ambassador in Washington for the Republic of China, but unfortunately, this report never ends with the media practicing his idea in his mother country. This phenomenon is obviously worthy of serious studies.

As media convergence progresses, these six forces in the media system in China will work together more closely, and some new joint effects may be produced in some new ways. This may open up new directions in exploring the mechanism of the media system in China. For example, the new Public Service Announcements being aired in CCTV 2014 Spring Festival Gala is obviously a joint effort of Party Force, Governmental Force, Capital Force, Individual Force and Cultural Force. The PSAs all looked like New Year's wishes from CCTV to the audience, but they were sponsored by brands, and, at the end of a given PSA, the brand's name is clearly visible. They were all politically appropriate, economically profitable and culturally positive, which made every player in the media system happy. CCTV declared that the Gala would be "Zero Advertising" (Ziwei 2014), so the PSA was used as a product placement, in which "product" could be a combined message of propaganda, commercial exposure and cultural festival greeting.

This paper covers just initial research aimed at establishing a framework analysing the media system in China, which is, overall, a fundamentally qualitative model. Further discussion, especially quantitative research, is encouraged to use this model to reveal the systematic dynamics of the media system in China.

\section{References}

Boxu, Y. (2010). Social spaces and new media: Some reflections on the modernization process in China. Procedia-Social and Behavioral Sciences, 2(5), 6941-6947.

Burkitt, L. (2011). China bans commercials during TV dramas-WSJ. Retrieved November 04, 2014, from http://online.wsj.com/news/articles/SB10001424052970203802204577066080663152966.

Chin, J. (2013). Former CCTV journalist slams censorship in open letter-China real time report-WSJ. Retrieved November 04, 2014, from http://blogs.wsj.com/chinarealtime/2013/12/02/former-cctvjournalist-slams-censorship-in-open-letter/.

Dobek-Ostrowska, B. (2010). Comparative media systems: European and global perspectives (pp. 41-62). Budapest: Central European University Press.

Fairbank, J. K., \& Goldman, M. (2006). China: A new history. Cambridge: Harvard University Press.

Fang, T. (2012). Yin Yang: A new perspective on culture. Management and Organization Review, 8(1), 25-50.

Faure, G. O., \& Fang, T. (2008). Changing Chinese values: Keeping up with paradoxes. International Business Review, 17(2), 194-207.

Hofstede, G., \& Bond, M. H. (1988). The Confucius connection: From cultural roots to economic growth. Organizational Dynamics, 16(4), 5-21.

Hu, J. (2011). Property Law of the People's Republic of China-China.org.cn. Retrieved November 04, 2014, from http://www.china.org.cn/china/LegislationsForm2001-2010/2011-02/11/content_21897 791.htm.

Martin, J. (2009). When China rules the world: The rise of the middle kingdom and the end of the western world. When China rules the world: The rise of the middle kingdom and the end of the western world.

McKenzie, R. (2006). Comparing media from around the world. Boston: Pearson/Allyn and Bacon. 
Merritt, D., \& Rosen, J. (1995). Imagining public journalism: An editor and scholar reflect on the birth of an idea. Roy W. Howard Project, School of Journalism, Indiana University.

Millward, S. (2013). Sina Weibo clocks 34,977 posts in first SECOND of Chinese New Year. Retrieved November 04, 2014, from https://www.techinasia.com/sina-weibo-34977-posts-first-second-chinese -new-year/.

Murphy, R. (2007). The paradox of the state-run media promoting poor governance in China: Case studies of a party newspaper and an anticorruption film. Critical Asian Studies, 39(1), 63-88. doi: $10.1080 / 14672710601171723$.

Oates, S. (2007). The neo-Soviet model of the media. Europe-Asia Studies, 59(8), 1279-1297.

Ostini, J., \& Ostini, A. Y. H. (2002). Beyond the four theories of the press: A new model of national media systems. Mass Communication and Society, 5(1), 41-56.

Passin, H. (1963). Writer and journalist in the transitional society. Communications and Political Development, 82-123.

Qianwen, L. (2013). CCTV's spring festival gala: Glory days gone-People's daily online. Retrieved November 04, 2014, from http://english.people.com.cn/90782/8135324.html.

Rosen, J. (1996). Getting the connections right: Public journalism and the troubles in the press. New York: Twentieth Century Fund.

Rosen, J., \& Merritt, D. (1994). Public journalism: Theory and practice. New York: Kettering Foundation.

Schwankert, S. (2013). Feng Xiaogang to Direct 2014 Spring Festival Gala : the Beijinger. Retrieved November 04, 2014, from http://www.thebeijinger.com/blog/2013/07/11/feng-xiaogang-direct2014-spring-festival-gala.

Siebert, F. S. (1956). Four theories of the press: The authoritarian, libertarian, social responsibility, and Soviet communist concepts of what the press should be and do. Champaign: University of Illinois Press.

Sparks, C. (2008). Media systems in transition: Poland, Russia, China. Chinese Journal of Communication, 1(1), 7-24. doi:10.1080/17544750701861871.

Stockmann, D. (2012). Media commercialization and authoritarian rule in China. Cambridge: Cambridge University Press.

Townsend, J. (1992). Chinese nationalism. The Australian Journal of Chinese Affairs, 27, 97-130.

Zhao, Y. (1998). Media, market, and democracy in China: Between the party line and the bottom line. Champaign: University of Illinois Press.

Zhao, Y. (2004). The state, the market, and media control in China. In Who owns the media? : Global trends and local resistances (pp. 179-212). Retrieved from Contributor biographical information http://www.loc.gov/catdir/bios/hol055/2003064130.html. Publisher description http://www.loc.gov /catdir/description/hol053/2003064130.html. Table of contents http:/www.loc.gov/catdir/toc/ hol051/2003064130.html.

Ziwei, G. (2014). Chinatopix-China news, China hot issues, China Business, politics, sports, entertainment, technology, society, culture and travel news. Retrieved November 04, 2014, from http://www.chinatopix.com/articles/1118/20140127/2014-cctv-spring-festival-gala-remain-style. htm\#.UvTgQfZvAXz.

侯迎忠. (2005). 20 世纪初民族新闻业的专业主义解读. 湖南大学学报: 社会科学版, 19(2), 122-125. 史仲文, 陈桥生. (2010). 中国文化 (pp. 56-61). 五洲传播出版社.

吴永强. (2012)。重庆北碚区委书记雷政富被免职 网络监督再发挥作用_中国广播网. Retrieved November 04, 2014, from http://china.cnr.cn/ygxw/201211/t20121124_511403805.shtml.

吴飞, \& 吴风. (2004). 新闻专业主义理念的建构. 中国人民大学学报, 6, 122-129.

崔保国. (2013). 2013 年中国传媒发展报告. 社会科学文献出版社. 